\author{
냉각곡선 분석을 통한 편상흑연주철의 공정반응에 미치는 \\ 희토류원소 및 냉각속도의 영향 평가 \\ 이상환 · 박승연 · 이상목 · 김명호* \\ 한국생산기술연구원 주조공정연구그룹, *인하대학교 금속공학과
}

\title{
Evaluation of Effects of Rare Earth Element and Cooling Rate on the Eutectic Reaction of Flake Graphite Cast Irons by Cooling Curve Analysis
}

\author{
Sang-Hwan Lee, Seung-Yeon Park, Sang-Mok Lee ${ }^{\dagger}$ and Myung-Ho Kim* \\ Liquid Processing \& Casting Technology R\&D Group, Korea Institute of Industrial Technology, Incheon 406-840, Korea \\ *Metallurgical Engineering, Inha University, Incheon 402-751, Korea
}

\begin{abstract}
The effects of rare earth element (R.E.) and cooling rate on the eutectic reaction of flake graphite cast irons were studied by combined analysis of macro/micro-structure and cooling curve data. The correlation between eutectic reaction parameter and macro/ micro-structure was systematically investigated. Two sets of chemical compositions with the different addition of R.E. were designed to cast. Three types of molds for cylindrical specimens with the different diameters were prepared to analyze cooling rate effect. The difference between undercooling temperature and cementite eutectic temperature $\left(\Delta T_{1}=T_{U}-T_{E, C}\right)$, which is increased by adding R.E. and decreased by increasing cooling rate, is considered to be a suitable eutectic reaction parameter for predicting graphite morphology. According to the criterion, A-type graphite is mainly suggested to form for $\Delta \mathrm{T}_{1}$ over $20^{\circ} \mathrm{C}$. Eutectic reaction time $(\Delta t)$, which is decreased by adding R.E. or increasing cooling rate, is a suitable eutectic reaction parameter for predicting eutectic cell size. Eutectic cell size is found to decrease in a proportion to the decrease of $\Delta t$.
\end{abstract}

Key words : Flake graphite cast irons, Eutectic reaction, Rare earth element, Cooling rate, Cooling curve.

\section{1. 서 론}

최근 자동차 산업 분야에서는 연비 향상, 배기가스 저감 및 환경규제 대응 등이 가장 빈번하게 언급되는 화제이자 가장 시급하게 해결해야 할 과제이다. 독일, 일본 그리고 미국 등의 자동차 선진국들은 2014년부터 시행되는 Euro-6에 대응하기 위해 자동차 핵심부품의 경량화 및 고특성화를 위한 연구개발 에 더욱 박차를 가하고 있는 상황이다. 편상흑연주철(Flake Graphite Cast Iron)은 가격이 싸고, 주조성, 가공성 및 진동감 쇠성 등이 매우 우수한 소재이다[1-9]. 비철계 소재 대신 편상 흑연주철을 사용하여 자동차용 주물부품을 박육화할 수 있다면,
부품 중량을 비철계 주물부품 수준으로 가볍게 하면서, 특성 및 성능을 비철계 주물부품에 비하여 획기적으로 향상시킬 수 있다[10,11].

편상흑연주철 부품의 박육화에는 많은 기술적 어려움이 따른 다. 냉각속도가 빨라질수록 형성되기 쉬운 취약한 조직인 칠 (Chill)의 억제, 주물두께가 얇아짐에 따라 부족해지는 강도와 유 동성의 증가 등이다. 편상흑연주철 부품의 박육화 시 칠 조직을 억제하기 위해서는 적정량의 $\mathrm{S}$ 가 포함된 용탕에 희토류원소 (Rare Earth Element, R.E.)를 첨가하는 것이 효과적이다. R.E. 를 $\mathrm{Mn}$ 및 $\mathrm{S}$ 대비 적절한 함량을 첨가할 경우에 (R.E.,Mn) $\mathrm{S}_{\mathrm{y}}$ 형태의 화합물이 형성되는데, 이 복합황화물이 흑연의 핵생성자
Received: December 24, 2012 ; Accepted: February 6, 2013

Corresponding author: Sang-Mok Lee (KITECH)

Tel: +82-32-850-0201, Fax: +82-32-850-0200

E-mail: smlee@kitech.re.kr
Journal of Korea Foundry Society

2013. Vol. 33 No. 1, pp. 013 021

http://dx.doi.org/10.7777/jkfs.2013.33.1.013

ISSN 1598-706X

(C) Korea Foundry Society, All rights reserved.

This is an Open-Access article distributed under the terms of the Creative Commons Attribution Non-Commercial License (http://creativecommons.org/licenses/by-nc/3.0) which permits unrestricted non-commercial use, distribution, and reproduction in any medium, provided the original work is properly cited. 
리로 작용하여 칠을 억제하기 때문이다[12-18].

냉각곡선을 흔히 용탕의 지문이라고 한다. 냉각곡선은 응고 및 상변태 과정의 전반적인 정보를 내포하고 있기 때문이며, 냉각곡선을 잘 분석하여 미세조직, 특성 및 결함 등을 예측할 수 있다[9,14,19-22]. 아공정주철(Hypoeutectic Cast Iron)의 경우에 흑연은 공정반응에 의해서 형성되기 시작하는데, 이 공 정반응에 의한 흑연 형성거동을 이해하고 예측하는데 냉각곡선 을 유용하게 활용할 수 있다. 본 연구에서는 조직과 냉각곡선 의 분석을 통해 일정량의 $\mathrm{S}$ 를 함유하고 있는 편상흑연주철의 공정반응에 미치는 R.E. 첨가 및 냉각속도 증가의 영향을 고 찰하였다. 냉각곡선으로부터 구해진 다양한 공정반응 인자들 중 에서 흑연, 공정셀 등 공정반응 조직의 예측에 적합한 인자를 검토하였다.

\section{2. 실험 방법}

\section{1 화학 조성}

$250 \mathrm{MPa}$ 급 인장강도를 가진 편상흑연주철의 경우에 기본원소 로써 포함되는 $\mathrm{C}, \mathrm{Si}$ 및 $\mathrm{Mn}$ 의 함량은 각각 3.0 3.6, 1.8 2.4 및 $0.6 \sim 0.8 \mathrm{wt} \%$ 수준이다. 본 연구에서는 $\mathrm{Fe}-3.3 \mathrm{wt} \% \mathrm{C}-2.1 \mathrm{wt} \%$ $\mathrm{Si}-0.7 \mathrm{wt} \% \mathrm{Mn}-0.1 \mathrm{wt} \% \mathrm{~S}$ 를 기준조성으로 채택하였다. 기준조성의 열역학적 공정온도는 JMatPro [23]로 계산하였다. 안정 평형조 건으로 계산한 흑연 공정온도(Graphite Eutectic Temperature, $\mathrm{T}_{\mathrm{E}, \mathrm{G}}$ )는 $1157.1^{\circ} \mathrm{C}$ 이다. 준안정 평형조건으로 계산한 시멘타이트 공정온도(Cementite Eutectic Temperature, $\mathrm{T}_{\mathrm{E}, \mathrm{C}}$ )는 $1121.8^{\circ} \mathrm{C}$ 이다. 실험시편의 화학조성은 분광분석기(Spark Emission Spectrometer, SES, OBLF QSN-750)로 측정되었다. 분석한 화학조성을 Table 1에 정리하였다. No. 1과 2의 두 실험조성 은 모두 기준조성을 목표값으로 하였고, No. 2의 경우에만 R.E.를 첨가하였다. R.E.는 $65 \mathrm{wt} \% \mathrm{Ce}-35 \mathrm{wt} \% \mathrm{La}$ 함량의 미시메 탈(Misch Metal)을 사용하였고, 전체 용탕량의 $0.3 \mathrm{wt} \%$ 를 첨 가하였다.

\section{2 주형 제작}

편상흑연주철의 공정반응에 미치는 냉각속도의 영향을 분석하 기 위해 원통형 시편을 여러 가지 직경으로 주조하였다. 냉각 속도가 각각 다른 원통형 시편들의 주조와 이 시편들의 냉각 곡선 측정이 가능하도록 각 주형들이 설계되었고, 이 주형들의 도면을 Fig. 1에 나타내었다. 주형은 원통형 시편의 높이가 $50 \mathrm{~mm}$ 이고, 직경이 각각 30,20 및 $13 \mathrm{~mm}$ 가 되도록 세 가 지 크기로 제작되었다. 열전대는 원통형 시편의 정중앙 부위를 측정하도록 주형에 설치되었다. 쉘 주형법(Shell Molding
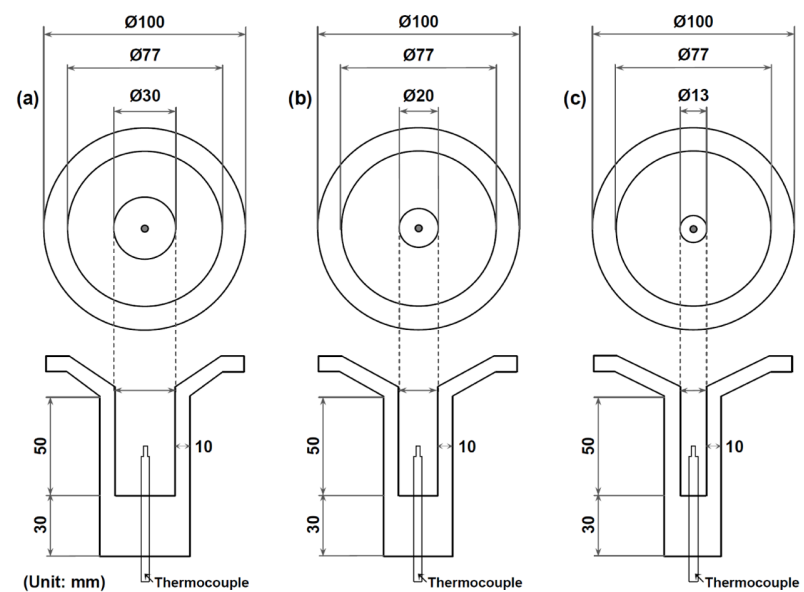

Fig. 1. Three types of molds for cylindrical specimens with different diameters; (a) $\phi 30$, (b) $\phi 20$ and (c) $\phi 13$.
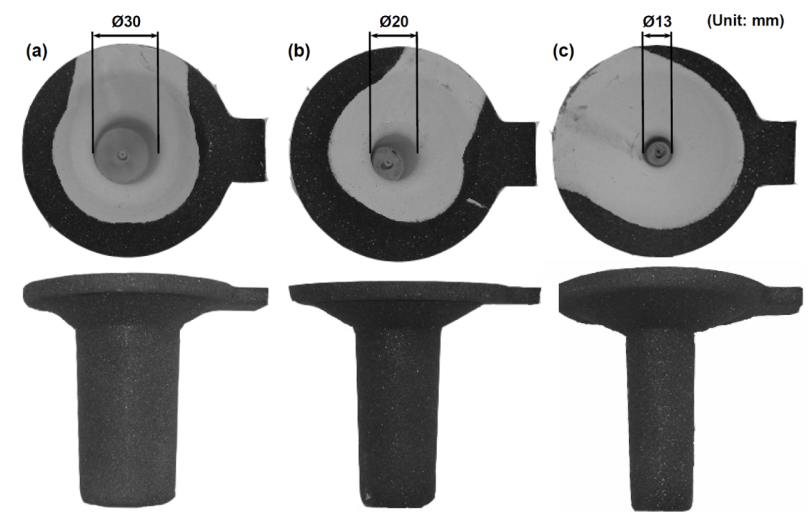

Fig. 2. Three types of molds produced by shell molding process; (a) $\phi 30$, (b) $\phi 20$ and (c) $\phi 13$.

Process)으로 제작한 주형들의 사진을 Fig. 2에 나타내었다. 원 통형 시편의 냉각속도는 직경이 30,20 및 $13 \mathrm{~mm}$ 인 경우에 각각 2 3, 4 5 및 $12 \sim 13^{\circ} \mathrm{C} / \mathrm{sec}$ 인 것으로 나타났다. 칠 깊이 (Chill Depth)를 측정하기 위해 쐐기형 시편을 주조하였다. 쐐 기형 시편용 주형은 ASTM A 367 (1C) 규격[24]에 따라 $\mathrm{CO}_{2}$ 주형법 $\left(\mathrm{CO}_{2}\right.$ Molding Process)으로 제작되었다. 제작된 주 형을 $20 \mathrm{~mm}$ 두께의 동판 위에 올려놓고, 용탕을 주입하였다.

\section{3 시편 주조}

용해공정에는 $75 \mathrm{~kW}$ 출력의 고주파 유도로가 이용되었다. 선철 $22 \mathrm{~kg}$ 과 고철 $6 \mathrm{~kg}$ 을 장입하여, 용탕량이 $28 \mathrm{~kg}$ 이 되도록

Table 1. Analyzed chemical compositions (wt\%).

\begin{tabular}{ccccccc}
\hline Specimen & C & Si & Mn & S & Remarks \\
\hline No. 1 & 3.27 & 2.12 & 0.78 & 0.1 & 0.1 \\
No. 2 & 3.25 & 2.11 & 0.71 & 0.1 & 0.1 \\
\hline
\end{tabular}


하였다. 용해온도를 $1,500 ~ 1,530^{\circ} \mathrm{C}$ 정도로 유지하다가, 출탕공정 직전에 용탕을 순간적으로 가열한 뒤 $1,550^{\circ} \mathrm{C}$ 의 최고 용해온도 에서 가열을 중단하였고, $1,530^{\circ} \mathrm{C}$ 에서 출탕하였다. 알루미늄 호 일에 싼 미시메탈을 래들(Ladle)에 넣어서 출탕과 동시에 접종 처리하였다. 용탕 교반 및 슬래그(Slag) 제거를 한 후 $1,400^{\circ} \mathrm{C}$ 에서 원통형 시편용 주형과 쐐기형 시편용 주형에 용탕을 주 입하였다.

\section{4 측정 및 평가}

광학현미경(Optical Microscope, OM, Nikon Epiphot-200) 을 이용하여 흑연 조직 및 공정셀 조직을 각각 100 배율 및 12.5 배율로 관찰하였다. 원통형 시편의 정중앙 부위를 관찰하였 다. 흑연 조직은 ASTM A 247 규격[25]에 따라 분류되었다. 공정셀 조직의 관찰을 위한 시편의 에칭(Etching)에는 Stead 시약을 사용하였다. 공정셀 크기 및 수는 문헌[26-29]에 소개 된 방법을 이용하여 측정하였다. 공정셀 크기 측정법을 간략히 소개하면 다음과 같다. 광학현미경 사진에서 가장 큰 다섯 개 의 공정셀을 선별한다. 선별한 각 공정셀들의 크기를 구하고, 이들의 평균값을 대표적 공정셀 크기로 활용한다. 이 때 각 공정셀의 크기는 공정셀의 중심에서 수직방향으로 교차하는 두 직선을 그린 뒤 이 직선들 상에서 측정한 두 직경의 평균값으 로 한다. 또한 공정셀 수 측정법은 다음과 같다. 광학현미경 사진에서 단위면적이 될 직사각형을 그린다. 직사각형 내의 공 정셀 수를 합산하고, 이를 단위면적으로 나눈 값을 대표적 공 정셀 수로 활용한다. 이 때 직사각형의 내부에 완전히 포함되 는 공정셀들은 1 개로 인정하여 합산한다. 직사각형의 네 변과
교차하는 공정셀들은 0.5 개로 인정하여 합산한다. 마지막으로 직사각형의 네 꼭지점에는 공정셀이 모두 교차하고 있다고 가 정하여 1을 추가로 합산한다. 본 연구에서는 $20 \mathrm{~mm}^{2}(=5 \mathrm{~mm}$ $\times 4 \mathrm{~mm})$ 를 단위면적으로 사용하였다. 칠 깊이는 ASTM A 367 규격에 따라 쐐기형 시편으로부터 측정되었다. 백선화 칠 깊이(Clear Chill Depth) 및 전체 칠 깊이(Total Chill Depth) 를 구분하여 측정하였다. 냉각곡선은 원통형 시편용 주형에 설 치된 $\mathrm{K}$ 형 열전대와 온도이력 기록기(Temperature Data Logger) 를 연결하여 측정하였다. 측정한 냉각곡선으로부터 여러 가지 공정반응 인자들을 구하였고, 이 인자들을 조직과 비교 분석하 였다.

\section{3. 결과 및 고찰}

\section{1 흑연 조직에 미치는 영향}

흑연 조직을 관찰하기 위한 미세조직 사진을 Fig. 3에 나타 내었다. 실험조건이 No. 1( $\phi 30)$ 및 2( $\phi 30)$ 인 두 경우에서 모 두 흑연 조직은 $\mathrm{A}$ 형이 대부분인 것으로 관찰되었다. 시편직경 이 $30 \mathrm{~mm}$ 인 경우에 R.E. 첨가에 의해 $\mathrm{A}$ 형 흑연 길이가 증가 하는 것이 확인되었다. 실험조건이 No. $1(\phi 2))$ 인 경우에 $\mathrm{A}$ 형 및 $\mathrm{B}$ 형 흑연이 각각 절반 정도씩 관찰되었다. 실험조건이 No. 2(\$20)인 경우에 A형 흑연이 주로 관찰되었고, B형 흑연이 일 부 관찰되었다. 시편직경이 $20 \mathrm{~mm}$ 인 경우에 R.E. 첨가에 의해 $\mathrm{A}$ 형 흑연 비율이 증가하고, $\mathrm{B}$ 형 흑연 비율이 감소하는 것이 확인되었다. 실험조건이 No. 1( $\phi 13)$ 인 경우에 $\mathrm{D}$ 형 흑연이 주 로 관찰되었고, $\mathrm{E}$ 형 흑연이 일부 관찰되었다. 실험조건이 No.

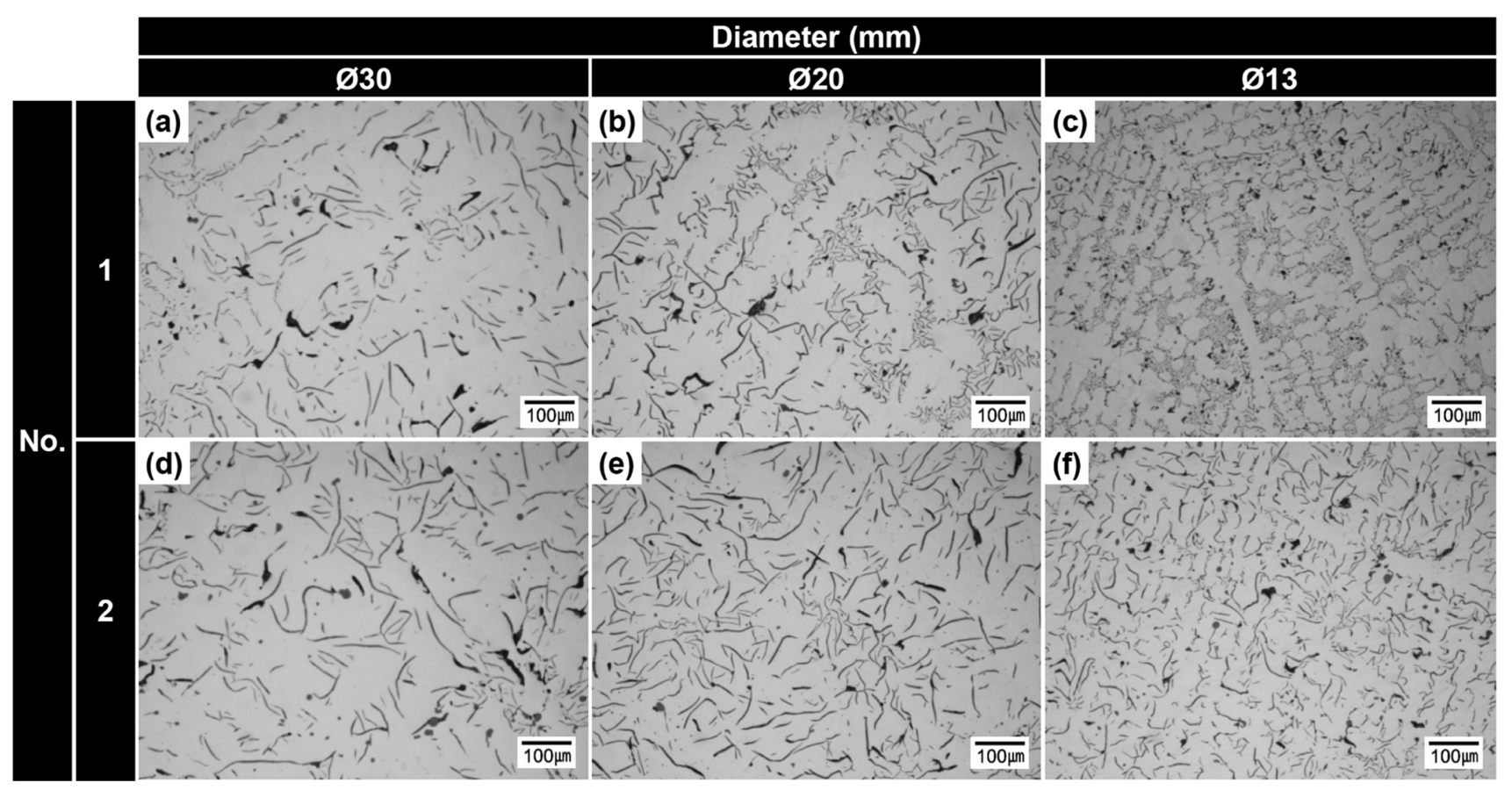

Fig. 3. Graphite morphology of six specimens with the variations of R.E. addition and specimen diameter. 
2(\$13)인 경우에 $\mathrm{A}$ 형 흑연이 주로 관찰되었고, $\mathrm{B}$ 형 및 $\mathrm{E}$ 형 흑연이 일부 관찰되었다. 시편직경이 $13 \mathrm{~mm}$ 인 경우에 R.E. 첨 가에 의해 $\mathrm{A}$ 형 흑연 비율이 증가하고, $\mathrm{D}$ 형 흑연 비율이 감소 하는 것이 확인되었다. $\mathrm{A}$ 형 흑연 비율을 증가시키고, $\mathrm{D}$ 형 흑 연 비율을 감소시키는 R.E. 첨가의 영향은 냉각속도가 빠른 경우에 더 잘 나타났다. R.E.가 첨가되지 않은 경우에 냉각속 도가 증가(시편직경 $30 \rightarrow 20 \mathrm{~mm}$ 감소)함에 따라 $\mathrm{A}$ 형 흑연 비율은 감소하고, $\mathrm{B}$ 형 흑연 비율은 증가하는 것이 확인되었다. 냉각속도가 더욱 증가(시편직경 $20 \rightarrow 13 \mathrm{~mm}$ 감소)함에 따라 $\mathrm{A}$ 형 및 $\mathrm{B}$ 형 흑연 비율은 감소하고, $\mathrm{D}$ 형 흑연 비율은 증가하 는 것이 확인되었다. R.E.가 첨가된 경우에 냉각속도가 증가 (시편직경 $30 \rightarrow 20 \rightarrow 13 \mathrm{~mm}$ 감소)함에 따라 $\mathrm{B}$ 형 흑연 비율 은 약간 증가하고, $\mathrm{D}$ 형 흑연은 거의 형성되지 않는 것이 확인 되었다. A형 흑연 비율을 감소시키고, $\mathrm{D}$ 형 흑연 비율을 증가 시키는 냉각속도 증가의 영향은 R.E.가 첨가된 경우에 완화되
는 것으로 나타났다.

\section{2 공정셀 조직에 미치는 영향}

공정셀 조직을 관찰하기 위한 거시조직 사진을 Fig. 4에 나 타내었다. 공정셀 크기 및 수를 측정하여 Table 2와 Fig. 5에 나타내었다. R.E. 첨가에 의해 공정셀 크기는 시편직경이 30 , 20 및 $13 \mathrm{~mm}$ 인 경우에 각각 37,22 및 $42 \%$ 감소하였고, 공 정셀 수는 각각 $2.3,1.7$ 및 3.1배로 증가하였다. 공정셀 크기 를 감소시키고, 공정셀 수를 증가시키는 R.E. 첨가의 영향은 시 편직경이 $13 \mathrm{~mm}$ 인 경우에 강하게 나타났다. 냉각속도 증가(시 편직경 $30 \rightarrow 13 \mathrm{~mm}$ 감소)에 의해 공정셀 크기는 실험조성이 No. 1 및 2인 경우에 각각 61 및 $64 \%$ 감소하였고, 공정셀 수는 각각 4.2 및 5.7 배로 증가하였다. 공정셀 크기를 감소시키 고, 공정셀 수를 증가시키는 냉각속도 증가의 영향은 R.E. 첨 가 여부와 상관없이 거의 유사하게 나타났다.

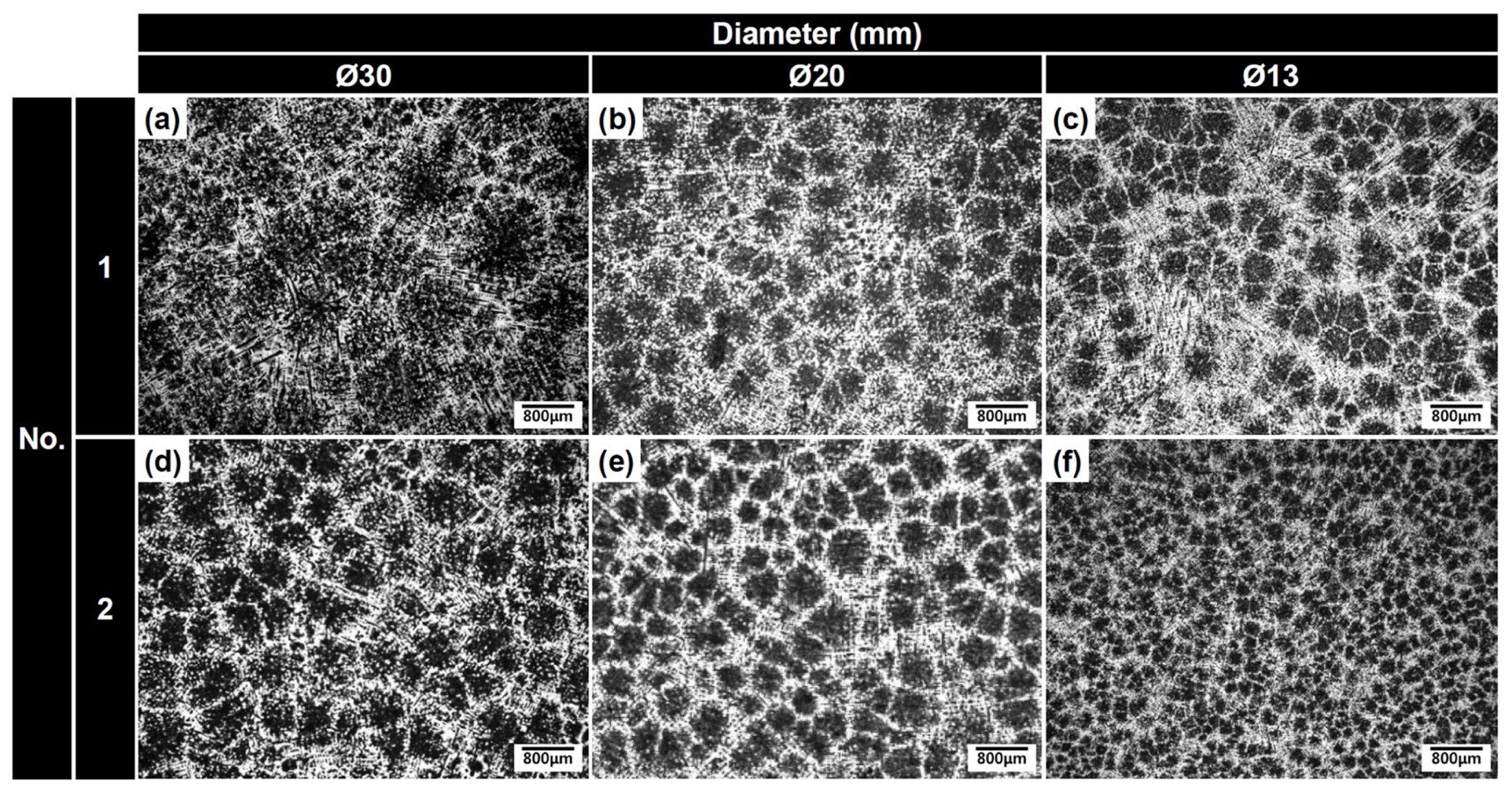

Fig. 4. Eutectic cell macrostructure of six specimens with the variations of R.E. addition and specimen diameter.

Table 2. Measured eutectic cell size/count and clear/total chill depth.

\begin{tabular}{|c|c|c|c|c|c|}
\hline \multirow{2}{*}{\multicolumn{2}{|c|}{ Specimen }} & \multicolumn{2}{|c|}{ Eutectic cell } & \multicolumn{2}{|c|}{ Chill } \\
\hline & & Eutectic cell size $(\mu \mathrm{m})$ & Eutectic cell count $\left(\# / \mathrm{mm}^{2}\right)$ & Clear chill depth $(\mathrm{mm})$ & Total chill depth (mm) \\
\hline \multirow{3}{*}{ No. 1} & $\phi 30$ & 1071 & 0.93 & \multirow{3}{*}{10} & \multirow{3}{*}{12} \\
\hline & $\phi 20$ & 540 & 2.20 & & \\
\hline & $\phi 13$ & 413 & 3.93 & & \\
\hline \multirow{3}{*}{ No. 2} & $\phi 30$ & 673 & 2.13 & \multirow{3}{*}{5} & \multirow{3}{*}{6} \\
\hline & $\phi 20$ & 420 & 3.75 & & \\
\hline & $\phi 13$ & 241 & 12.08 & & \\
\hline
\end{tabular}



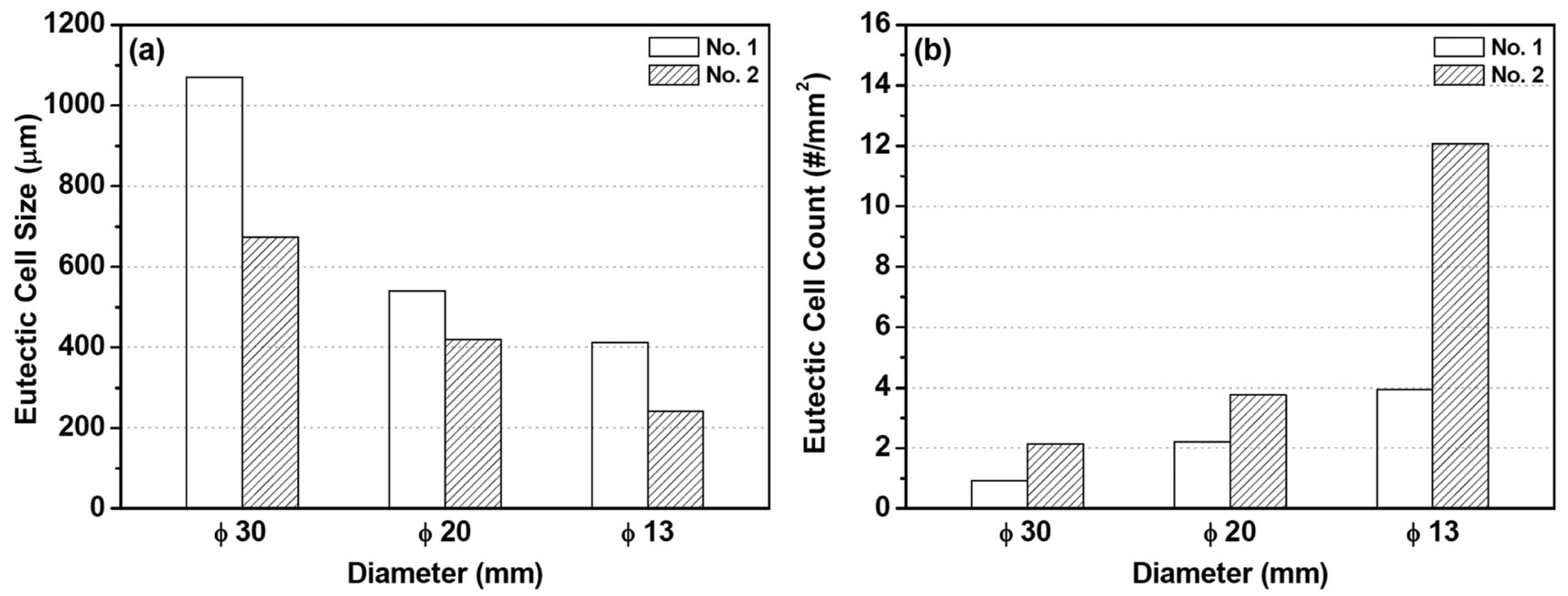

Fig. 5. Effects of R.E. addition and specimen diameter on (a) eutectic cell size and (b) eutectic cell count.

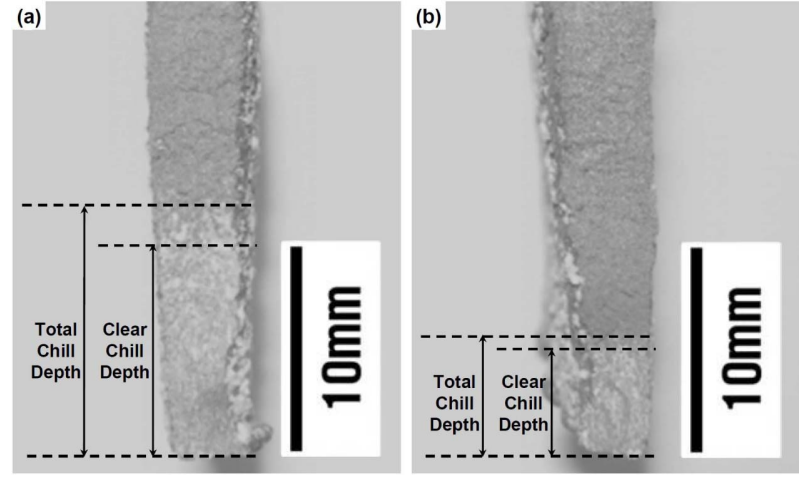

Fig. 6. Chill depth variations with different R.E. addition; (a) No. 1 and (b) No. 2.

\section{3 칠 조직에 미치는 영향}

칠 깊이를 측정하기 위한 시편의 사진을 Fig. 6에 나타내었

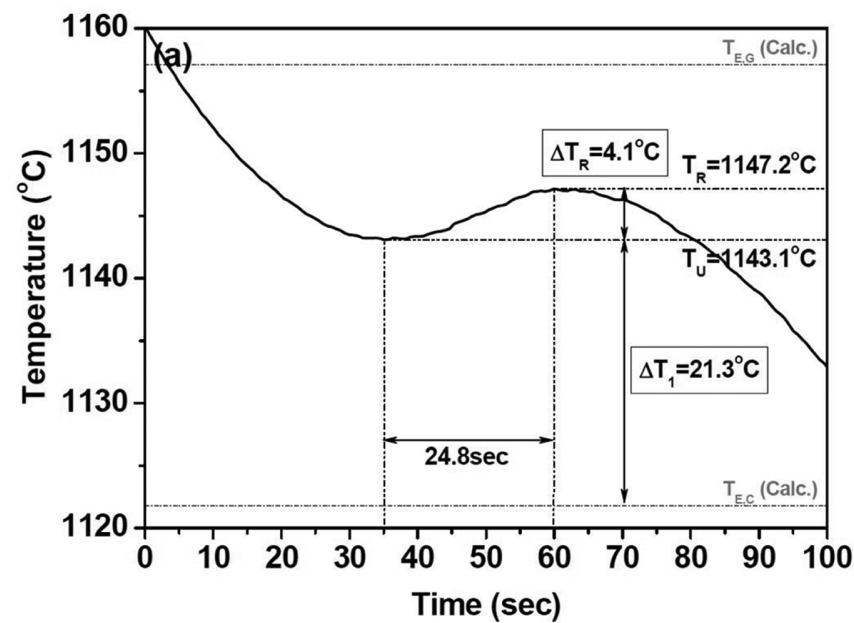

다. 측정한 칠 깊이는 Table 2에 정리하였다. R.E.가 첨가되지 않은 No. 1 실험조성의 경우에 칠 깊이는 $10 \mathrm{~mm}$ 이고, R.E. 가 첨가된 No. 2 실험조성의 경우에 칠 깊이는 $5 \mathrm{~mm}$ 인 것으 로 나타났다. R.E. 첨가에 의해 칠 깊이는 절반 수준으로 감 소하였다.

\section{4 과냉온도 $\left(T_{U}\right)$ 에 미치는 영향}

시편직경이 30,20 및 $13 \mathrm{~mm}$ 인 경우의 냉각곡선을 각각 Fig. 7 9에 나타내었다. 냉각곡선은 공정반응 구간을 위주로 나타내었고, $1160^{\circ} \mathrm{C}$ 에서의 시간이 0 이 되도록 이동되었다. Fig. 7 9에 나타낸 $\mathrm{T}_{\mathrm{E}, \mathrm{G}}$ 및 $\mathrm{T}_{\mathrm{E}, \mathrm{C}}$ 는 각각 기준조성의 흑연 및 시멘타이트 공정온도이며, 2.1절에서 언급한 열역학 계산 결과 이다. 본 연구에서 주로 검토하게 될 여러 가지 공정반응 인 자들을 Fig. 7 9의 냉각곡선으로부터 구하여 Table 3에 정리 하였다. 과냉온도(Undercooling Temperature, $\mathrm{T}_{\mathrm{U}}$ )는 $\mathrm{T}_{\mathrm{E}, \mathrm{G}}$ 이하

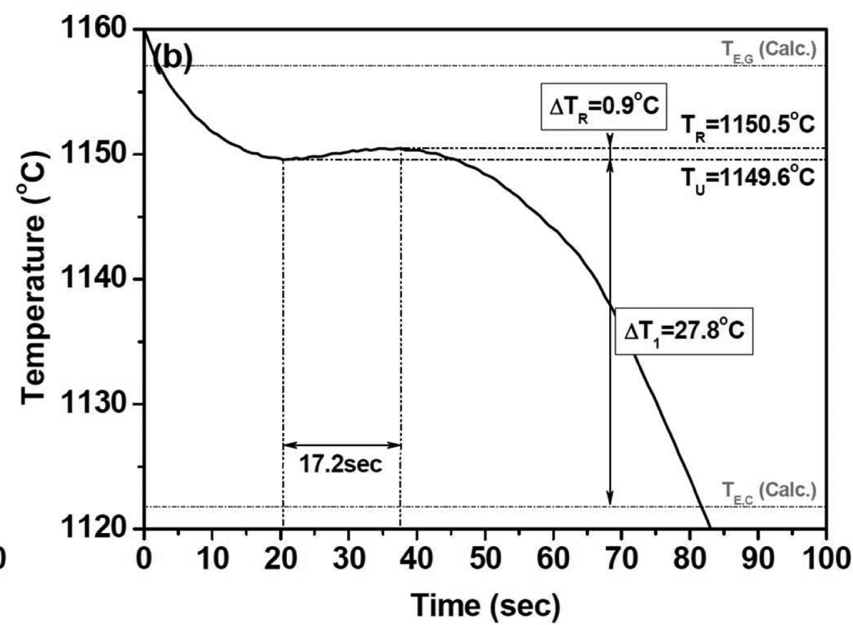

Fig. 7. Cooling curve of two specimens ( $\phi 30)$ with different R.E. addition; (a) No. 1 and (b) No. 2. 

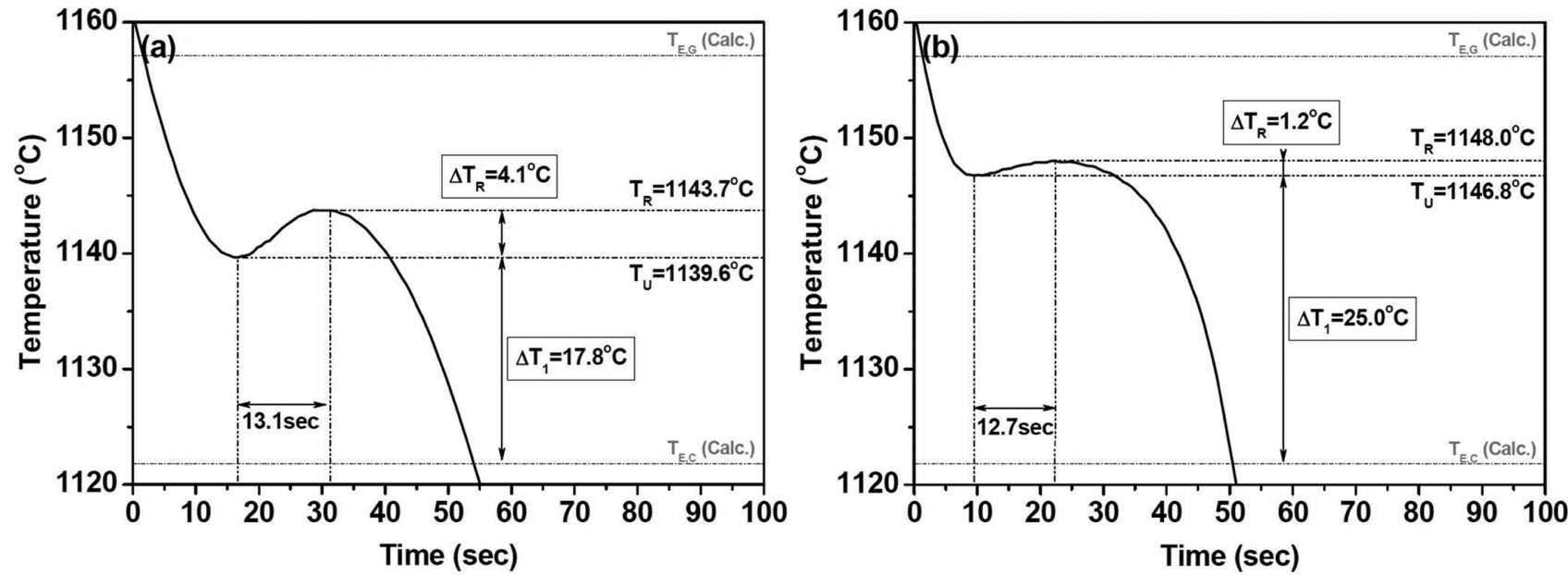

Fig. 8. Cooling curve of two specimens ( $\$ 20)$ with different R.E. addition; (a) No. 1 and (b) No. 2.
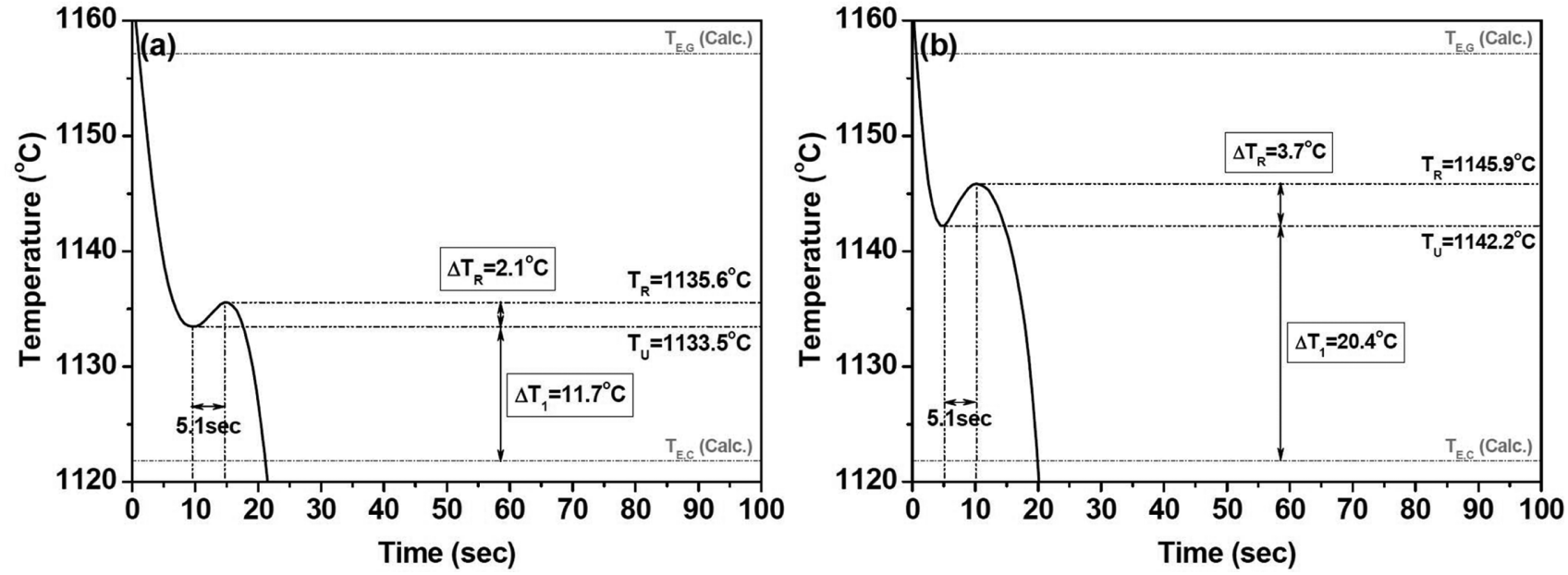

Fig. 9. Cooling curve of two specimens ( $\phi 13)$ with different R.E. addition; (a) No. 1 and (b) No. 2.

Table 3. Eutectic reaction parameters evaluated by thermodynamic data and cooling curve.

\begin{tabular}{|c|c|c|c|c|c|c|}
\hline \multicolumn{2}{|c|}{ Specimen } & $\mathrm{T}_{\mathrm{U}}\left({ }^{\circ} \mathrm{C}\right)$ & $\mathrm{T}_{\mathrm{R}}\left({ }^{\circ} \mathrm{C}\right)$ & $\Delta \mathrm{T}_{1}\left({ }^{\circ} \mathrm{C}\right)$ & $\Delta \mathrm{T}_{\mathrm{R}}\left({ }^{\circ} \mathrm{C}\right)$ & $\Delta \mathrm{t}(\mathrm{sec})$ \\
\hline \multirow{3}{*}{ No. 1} & $\phi 30$ & 1143.1 & 1147.2 & 21.3 & 4.1 & 24.8 \\
\hline & $\phi 20$ & 1139.6 & 1143.7 & 17.8 & 4.1 & 13.1 \\
\hline & $\phi 13$ & 1133.5 & 1135.6 & 11.7 & 2.1 & 5.1 \\
\hline \multirow{3}{*}{ No. 2} & $\phi 30$ & 1149.6 & 1150.5 & 27.8 & 0.9 & 17.2 \\
\hline & $\phi 20$ & 1146.8 & 1148.0 & 25.0 & 1.2 & 12.7 \\
\hline & $\phi 13$ & 1142.2 & 1145.9 & 20.4 & 3.7 & 5.1 \\
\hline
\end{tabular}

$\mathrm{T}_{\mathrm{U}}=$ undercooling temperature, $\mathrm{T}_{\mathrm{R}}=$ recalescence temperature, $\Delta \mathrm{T}_{1}=\mathrm{T}_{\mathrm{U}}-\mathrm{T}_{\mathrm{E}, \mathrm{C}}, \Delta \mathrm{T}_{\mathrm{R}}=\mathrm{T}_{\mathrm{R}}-\mathrm{T}_{\mathrm{U}}$, and $\Delta \mathrm{t}=\mathrm{t}\left(\mathrm{T}_{\mathrm{R}}\right)-\mathrm{t}\left(\mathrm{T}_{\mathrm{U}}\right)$.

에서 냉각곡선의 기울기 $(\mathrm{dT} / \mathrm{dt})$ 가 첫 번째로 0 이 되는 온도이 다. $\mathrm{T}_{\mathrm{U}}$ 에 도달한 순간을 흑연 공정반응의 개시시간으로 간주할 수 있다. $\mathrm{T}_{\mathrm{U}}$ 는 $\mathrm{T}_{\mathrm{E}, \mathrm{G}}$ 와의 차이가 크지 않도록 하는 것이 좋으 며, 적절한 접종 처리에 의해 온도를 높일 수 있다[21]. $\mathrm{T}_{\mathrm{U}}$ 에
미치는 R.E. 첨가 및 냉각속도 증가의 영향을 Fig. 10(a)에 나타내었다. $\Delta \mathrm{T}_{1}$ 은 $\mathrm{T}_{\mathrm{U}}$ 와 $\mathrm{T}_{\mathrm{E}, \mathrm{C}}$ 의 차이 $\left(=\mathrm{T}_{\mathrm{U}}-\mathrm{T}_{\mathrm{E}, \mathrm{C}}\right)$ 를 나타내는 공정반응 인자이다[19-22]. $\mathrm{T}_{\mathrm{U}}$ 가 높을수록 좋기 때문에 $\Delta \mathrm{T}_{1}$ 은 넓을수록 좋다. 실험조건에 따른 $\mathrm{T}_{\mathrm{U}}$ 와 $\Delta \mathrm{T}_{1}$ 의 변화량은 본 연 

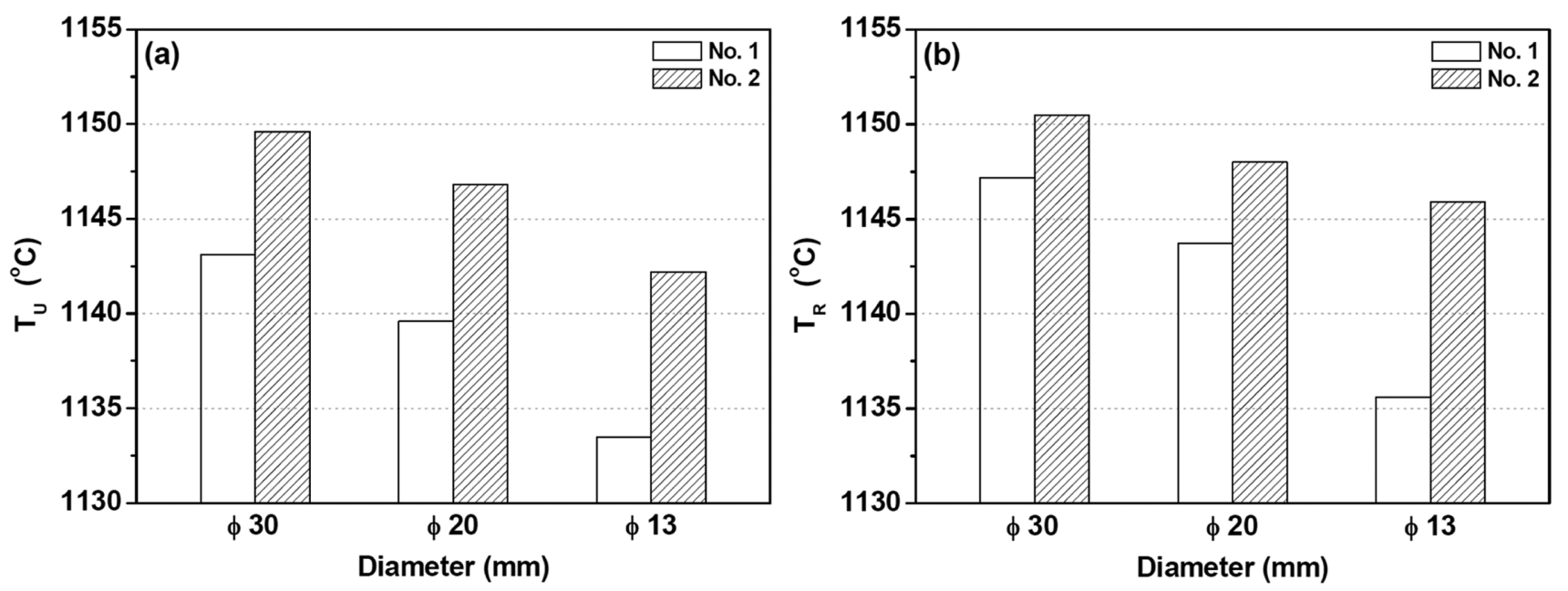

Fig. 10. Effects of R.E. addition and specimen diameter on (a) $T_{U}$ and (b) $T_{R}$.

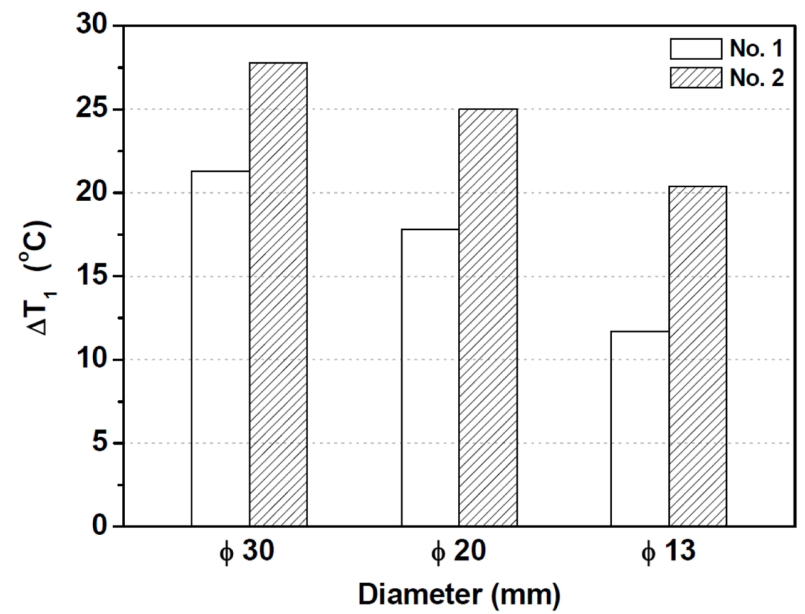

Fig. 11. Effects of R.E. addition and specimen diameter on $\Delta \mathrm{T}_{1}$.

구에서는 완전히 동일하다. R.E.의 열역학 정보가 충분하지 못 하여, 두 실험조성의 $\mathrm{T}_{\mathrm{E}, \mathrm{C}}$ 를 동일한 값으로 가정했기 때문이다. $\Delta \mathrm{T}_{1}$ 에 미치는 R.E. 첨가 및 냉각속도 증가의 영향을 Fig. 11 에 나타내었다. R.E. 첨가에 의해 $\Delta \mathrm{T}_{1}$ 은 시편직경이 30,20 및 $13 \mathrm{~mm}$ 인 경우에 각각 $6.5,7.2$ 및 $8.7^{\circ} \mathrm{C}$ 증가하였다. $\Delta \mathrm{T}_{1}$ 을 증가시키는 R.E. 첨가의 영향은 냉각속도가 빠른 경우 에 더 잘 나타났다. 냉각속도 증가(시편직경 $30 \rightarrow 13 \mathrm{~mm}$ 감 소)에 의해 $\Delta \mathrm{T}_{1}$ 은 실험조성이 No. 1 및 2 인 경우에 각각 9.6 및 $7.4^{\circ} \mathrm{C}$ 감소하였다. $\Delta \mathrm{T}_{1}$ 을 감소시키는 냉각속도 증가의 영향은 R.E.가 첨가된 경우에 다소 약화되었다. $\Delta \mathrm{T}_{1}$ 이 $20^{\circ} \mathrm{C}$ 이 상으로 나타난 실험조건은 No. 1( $(30), 2(\phi 30), 2(\phi 20)$ 및 2(\$13)였고, 이들의 경우에 Fig. 3(a), (d), (e) 및 (f)과 같이 냉각속도에 상관없이 $\mathrm{A}$ 형 흑연 조직이 주로 형성되었다. $\Delta \mathrm{T}_{1}$ 은 흑연 형상의 예측에 적합한 공정반응 인자로 판단된다.

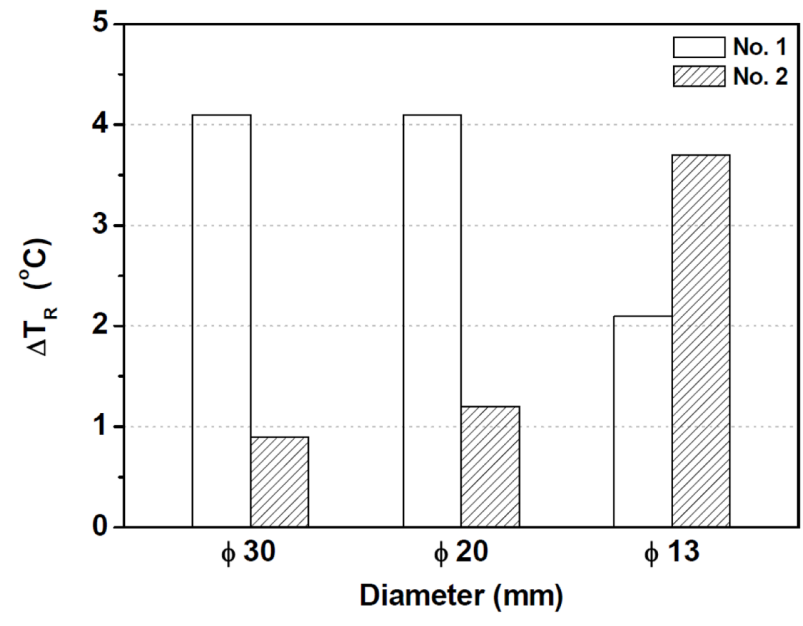

Fig. 12. Effects of R.E. addition and specimen diameter on $\Delta T_{R}$.

\section{5 재휘온도 $\left(T_{R}\right)$ 에 미치는 영향}

재휘온도(Recalescence Temperature, $\mathrm{T}_{\mathrm{R}}$ )는 $\mathrm{T}_{\mathrm{E}, \mathrm{G}}$ 이하에서 냉각곡선의 기울기(dT/dt)가 두 번째로 0 이 되는 온도이다. $\mathrm{T}_{\mathrm{R}}$ 에 도달한 순간을 흑연 공정반응의 종료시간으로 간주할 수 있 다. $\mathrm{T}_{\mathrm{R}}$ 는 $\mathrm{T}_{\mathrm{E}, \mathrm{G}}$ 와의 차이가 크지 않도록 하는 것이 좋다. $\mathrm{T}_{\mathrm{R}}$ 에 미치는 R.E. 첨가 및 냉각속도 증가의 영향을 Fig. 10 (b)에 나 타내었다. R.E. 첨가에 의해 $\mathrm{T}_{\mathrm{R}}$ 은 시편직경이 30,20 및 $13 \mathrm{~mm}$ 인 경우에 각각 $3.3,4.3$ 및 $10.3^{\circ} \mathrm{C}$ 증가하였다. $\mathrm{T}_{\mathrm{R}}$ 을 증가시키는 R.E. 첨가의 영향은 냉각속도가 빠른 경우에 더 잘 나타났다. 냉각속도 증가(시편직경 $30 \rightarrow 13 \mathrm{~mm}$ 감소)에 의해 $\mathrm{T}_{\mathrm{R}}$ 은 실험조성이 No. 1 및 2 인 경우에 각각 11.6 및 $4.6^{\circ} \mathrm{C}$ 감소하였다. $\mathrm{T}_{\mathrm{R}}$ 을 감소시키는 냉각속도 증가의 영향은 R.E.가 첨가된 경우에 약화되었다.

재휘도(Recalescence Degree, $\left.\Delta \mathrm{T}_{\mathrm{R}}\right)$ 는 $\mathrm{T}_{\mathrm{R}}$ 와 $\mathrm{T}_{\mathrm{U}}$ 의 차이 $\left(=\mathrm{T}_{\mathrm{R}}\right.$ $-\mathrm{T}_{\mathrm{U}}$ )를 나타내는 공정반응 인자이다[19-22]. $\Delta \mathrm{T}_{\mathrm{R}}$ 은 $2 \sim 5^{\circ} \mathrm{C}$ 정 


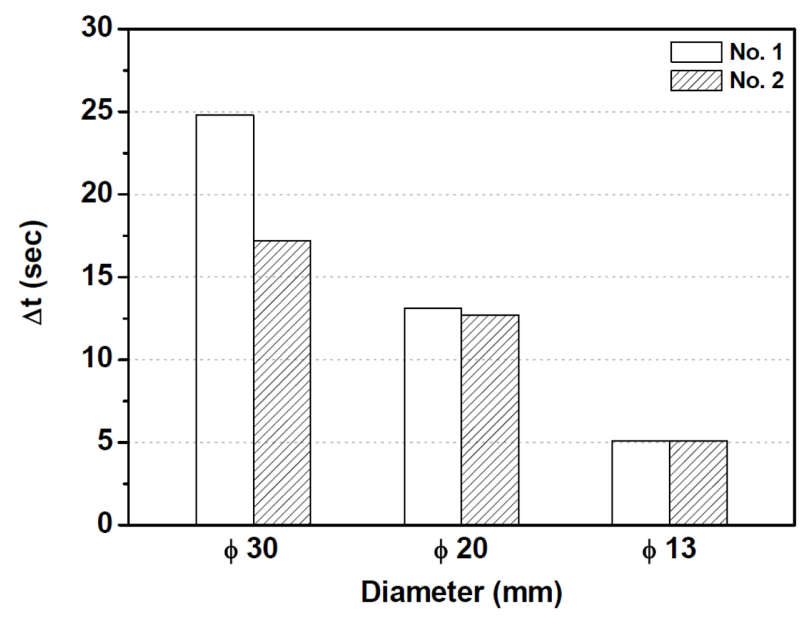

Fig. 13. Effects of R.E. addition and specimen diameter on $\Delta$ t.

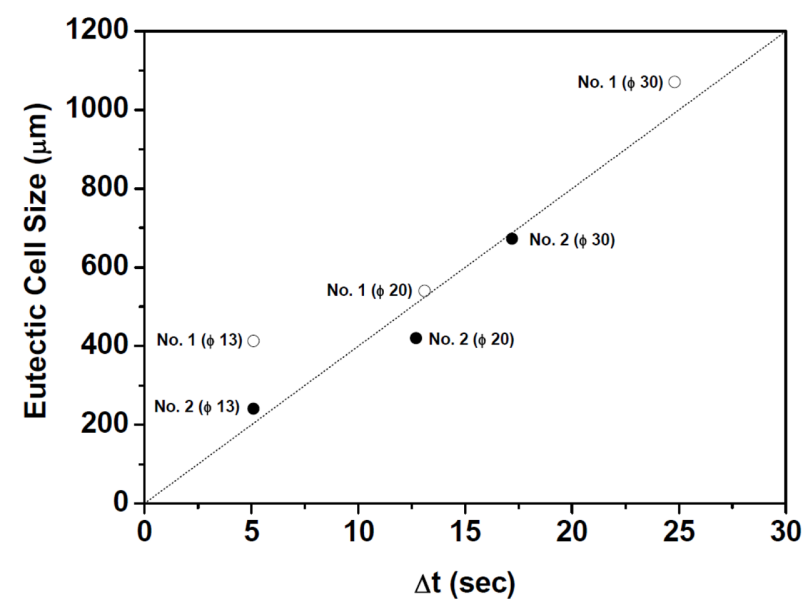

Fig. 14. Correlation between $\Delta \mathrm{t}$ and eutectic cell size.

도의 범위를 유지하는 것이 좋으며, 접종 처리에 의해 범위가 좁아진다고 알려져 있다[21]. $\Delta \mathrm{T}_{\mathrm{R}}$ 에 미치는 R.E. 첨가 및 냉 각속도 증가의 영향을 Fig. 12에 나타내었다. R.E. 첨가에 의 해 $\Delta \mathrm{T}_{\mathrm{R}}$ 은 시편직경이 30 및 $20 \mathrm{~mm}$ 인 경우에 각각 3.2 및 $2.9^{\circ} \mathrm{C}$ 감소하였으나, 시편직경이 $13 \mathrm{~mm}$ 인 경우에 $1.6^{\circ} \mathrm{C}$ 증가 하였다. $\Delta \mathrm{T}_{\mathrm{R}}$ 에 미치는 R.E. 첨가의 영향은 냉각속도에 따라 다른 변화 경향을 나타내었다. 냉각속도 증가(시편직경 $30 \rightarrow$ $13 \mathrm{~mm}$ 감소)에 의해 $\Delta \mathrm{T}_{\mathrm{R}}$ 은 실험조성이 No. 1 인 경우에 $2.0^{\circ} \mathrm{C}$ 감소하였고, 실험조성이 No. 2 인 경우에 $2.8^{\circ} \mathrm{C}$ 증가하 였다. $\Delta \mathrm{T}_{\mathrm{R}}$ 에 미치는 냉각속도 증가의 영향은 R.E.의 첨가 여 부에 따라 다른 변화 경향을 나타내었다. $\Delta \mathrm{T}_{\mathrm{R}}$ 은 온도 범위 값 이 작아서 실험적 오차가 발생할 여지가 크며, 조직과의 상관 관계가 불분명하다. $\Delta \mathrm{T}_{\mathrm{R}}$ 은 흑연 조직 및 공정셀 조직의 예측 에 적합하지 않은 공정반응 인자로 판단된다.

\section{6 공정반응 시간 $(\Delta t)$ 에 미치는 영향}

공정반응 시간 $(\Delta \mathrm{t})$ 은 $\mathrm{T}_{\mathrm{R}}$ 에서의 시간과 $\mathrm{T}_{\mathrm{U}}$ 에서의 시간의 차
이 $\left(=\mathrm{t}\left(\mathrm{T}_{\mathrm{R}}\right)-\mathrm{t}\left(\mathrm{T}_{\mathrm{U}}\right)\right)$ 를 나타내는 공정반응 인자이다. $\Delta \mathrm{t}$ 는 흑연 공정반응이 진행된 시간으로 간주할 수 있다. 냉각곡선은 $\mathrm{T}_{\mathrm{U}}$ 에 도달한 시점부터 공정셀의 성장이 개시되어 $\Delta t$ 동안에 온도가 증가하게 되고, $\mathrm{T}_{\mathrm{R}}$ 에 도달한 시점 이후에는 공정셀 간의 충돌 (Impingement)로 인해 성장이 중지되어 온도가 감소하게 된다. $\Delta$ t에 미치는 R.E. 첨가 및 냉각속도 증가의 영향을 Fig. 13에 나타내었다. R.E. 첨가에 의해 $\Delta \mathrm{t}$ 는 시편직경이 30 및 $20 \mathrm{~mm}$ 인 경우에 각각 7.6 및 0.4 초 감소하였고, 시편직경이 $13 \mathrm{~mm}$ 인 경우에는 변화가 없었다. $\Delta$ t를 감소시키는 R.E. 첨가의 영 향은 냉각속도가 빠른 경우에 거의 나타나지 않았다. 이는 냉 각속도 증가의 영향이 R.E. 첨가의 영향보다 $\Delta \mathrm{t}$ 의 감소에 더 주도적으로 작용하기 때문인 것으로 판단된다. 냉각속도 증가(시 편직경 $30 \rightarrow 13 \mathrm{~mm}$ 감소)에 의해 $\Delta \mathrm{t}$ 는 실험조성이 No. 1 및 2 인 경우에 각각 19.7 및 12.1 초 감소하였다. $\Delta t$ 를 감소시키는 냉각속도 증가의 영향은 R.E.가 첨가된 경우에 약화되었다. $\Delta \mathrm{t}$ 와 공정셀 크기의 상관관계를 Fig. 14에 나타내었다. $\Delta \mathrm{t}$ 의 감 소에 따라 공정셀 크기는 거의 비례적으로 감소하였다. $\Delta \mathrm{t}$ 는 공정셀 크기의 예측에 적합한 공정반응 인자로 판단된다.

\section{7 희토류원소(R.E.)와 냉각속도의 복합적 영향}

흑연 조직, 공정셀 조직 및 공정반응 인자에 미치는 R.E. 및 냉각속도의 영향은 대부분 일관성 있는 변화 경향으로 나 타났다. 흑연 조직, 공정셀 조직, $\mathrm{T}_{\mathrm{U}}, \Delta \mathrm{T}_{1}$ 및 $\mathrm{T}_{\mathrm{R}}$ 에 미치는 R.E. 첨가의 영향은 냉각속도가 빠른 경우에 더 강하게 나타났 다. 이는 두께가 얇은 박육 주물일수록 R.E. 첨가의 영향이 더 효과적으로 나타난다는 것을 의미한다. 흑연 조직, $\mathrm{T}_{\mathrm{U}}, \Delta \mathrm{T}_{1}, \mathrm{~T}_{\mathrm{R}}$ 및 $\Delta \mathrm{t}$ 에 미치는 냉각속도 증가의 영향은 R.E.가 첨가된 경우에 더 약하게 나타났다. 이는 R.E.가 첨가된 주물의 경우에 박육 화의 기술적 어려움을 해결하기가 용이하다는 것을 의미한다.

\section{4. 결 론}

조직 및 냉각곡선의 분석을 통해 일정량의 $\mathrm{S}$ 를 함유하는 편 상흑연주철의 공정반응에 미치는 희토류원소(R.E.) 첨가 및 냉 각속도 증가의 영향을 연구하였고, 다음과 같은 결론을 얻었다.

1) A형 흑연 비율은 R.E. 첨가에 의해 증가하였고, 냉각속 도 증가에 의해 감소하였다.

2) 공정셀 크기는 R.E. 첨가 및 냉각속도 증가에 의해 감소 하였다. 공정셀 수는 R.E. 첨가 및 냉각속도 증가에 의해 증 가하였다.

3) 과냉온도와 시멘타이트 공정온도의 차이 $\left(\Delta \mathrm{T}_{1}=\mathrm{T}_{\mathrm{U}}-\mathrm{T}_{\mathrm{E}, \mathrm{C}}\right)$ 는 R.E. 첨가에 의해 증가하였고, 냉각속도 증가에 의해 감소 하였다. $\Delta \mathrm{T}_{1}$ 이 $20^{\circ} \mathrm{C}$ 이상인 경우 냉각속도에 상관없이 $\mathrm{A}$ 형 흑 연 조직이 형성되었다. $\Delta \mathrm{T}_{1}$ 은 흑연 형상의 예측에 적합한 공 정 반응 인자이다.

4) 재휘도 $\left(\Delta T_{R}=T_{R}-T_{U}\right)$ 는 R.E. 첨가 및 냉각속도 증가에 의한 변화 경향이 일정하지 않았다. $\Delta \mathrm{T}_{\mathrm{R}}$ 은 흑연 조직 및 공정 
셀 조직의 예측에 부적합한 공정반응 인자이다.

5) 공정반응 시간 $(\Delta \mathrm{t})$ 은 R.E. 첨가 및 냉각속도 증가에 의해 감소하였다. $\Delta \mathrm{t}$ 의 감소에 따라 공정셀 크기는 거의 비례적으로 감소하였다. $\Delta t$ 는 공정셀 크기의 예측에 적합한 공정반응 인자 이다.

\section{참고문헌}

[1] Loria EA, Iron Age, "How Machinable are the Cast Irons?", 172 (1953) 158-161.

[2] Janowak JF and Gundlach RB, AFS Trans., "Improved Machinability of High Strength Gray Iron”, 93 (1985) 961-968.

[3] Millet P, Schaller R and Benoit W, J. Phys. Colloques, "High Damping in Grey Cast Iron", 46 (1985) 405-408.

[4] Bates CF, Modern Casting, "Study Examines Influences on Machinability of Iron Castings", 86 (1996) 36-39.

[5] Burke CM, Moore DJ, Parolini JR, Rundman KB and Waarala D, AFS Trans., "Machinalbility of Gray Cast Iron: A Drilling Study", 107 (1999) 567-575.

[6] O'Rourke R and Grander M, Gear Tech., "Cast Iron: A Solid Choice for Reducing Gear Noise", 16 (1999) 46-49.

[7] Murakami T, Inoue T, Shimura H, Nakano M and Sasaki S, Mater. Sci. Eng. A, "Damping and Tribological Properties of Fe-Si-C Cast Iron Prepared Using Various Heat Treatments", 432 (2006) 113-119.

[8] Collini L, Nicoletto G and Konečná R, Mater. Sci. Eng. A, "Microstructure and Mechanical Properties of Pearlitic Gray Cast Iron", 488 (2008) 529-539.

[9] Nakae H and Fujimoto K, Key Eng. Mater., "Influence of Ti on Graphite Morphological Transition in Flake Graphite Cast Iron", 457 (2011) 25-30.

[10] Tanaka K, Okamura T and Satou T, J. Jpn. Foundry Eng. Soc., "Thin Wall and Lightweight Cylinder Block Production Technology", 73 (2001) 527-533.

[11] Fritsche E, Giesserei-Rundschau, "Energy Efficiency and $\mathrm{CO}_{2}$ Emissions - Manufacture of Crankcases Made of Cast Iron versus Aluminium Alloy", 56 (2009) 160-164.

[12] Kowata T, Horie H, Hiratsuka S and Sato E, J. Jpn. Foundry Eng. Soc., "Effects of Rare Earth Elements on Chilling Tendency and Mechanical Properties of Flake Graphite Cast Irons with Different Carbon Equivalents", 68 (1996) 865-869.

[13] Kanno T, Kang I, Mizuki T and Nakae H, J. Jpn. Foundry Eng. Soc., "Effects of S, Mn and R.E. on Eutectic Temperature of Cast Iron", 73 (2001) 441-446.

[14] Lee SH, Hiratsuka S, Horie H, Kowata T and Choi CO, J. Jpn.
Foundry Eng. Soc., "Effect of Rare Earth/Sulfur Ratio on Graphite Morphology and Chill Depth in Flake Graphite Cast Iron", 74 (2002) 285-290.

[15] Kowata T, Lee SH, Horie H, Hiratsuka S and Hareyama T, J. Jpn. Foundry Eng. Soc., "Effect of Sulfide Shape on Graphitization of Flake Graphite Cast Iron", 74 (2002) 578-583.

[16] Hiratsuka S, Lee SH, Horie H, Kowata T and Choi CO, J. Jpn. Foundry Eng. Soc., "Effect of Fading on Mechanical Properties and Sulfide Shape in Rare Earth Element Added Flake Graphite Cast Iron", 74 (2002) 584-589.

[17] Kowata T, Horie H, Hareyama T, Aida T and Miyake M, J. Jpn. Foundry Eng. Soc., "Effects of Minor Elements on Mechanical Properties of Flake Graphite Cast Iron Using High Manganese Steel Sheet Scrap", 75 (2003) 743-748.

[18] Riposan I, Chisamera M, Stan S, Stefan E and Hartung C, Key Eng. Mater., "Role of Lanthanum in Graphite Nucleation in Grey Cast Iron", 457 (2011) 19-24.

[19] Kanno T, Kimura $\mathrm{H}$ and Nakae H, 64 ${ }^{\text {th }}$ World Foundry Congress, ATF, Paris (2000).

[20] Kanno T, Morinaka M and Nakae H, J. Jpn. Foundry Eng. Soc., "Relationship between Variation of Eutectic Temperature and Melt Quality in Cast Iron", 74 (2002) 305-311.

[21] Chisamera M, Riposan I, Stan S, Stefan E and Costache G, Chn. Foundry, "Thermal Analysis Control of In-Mould and Ladle Inoculated Grey Cast Irons”, 6 (2009) 145-151.

[22] Stan S, Chisamera M, Riposan I and Barstow M, J. Therm. Anal. Calorim., "Application of Thermal Analysis to Monitor the Quality of Hypoeutectic Cast Irons during Solidification in Sand and Metal Moulds", 110 (2012) 1185-1192.

[23] Saunders N, Guo Z, Li X, Miodownik AP and Schillé JP, JOM, "Using JMatPro to Model Materials Properties and Behavior", 55 (2003) 60-65.

[24] ASTM A 367 - 60, "Standard Test Methods of Chill Testing of Cast Iron" (1999).

[25] ASTM A 247 - 67, "Standard Test Method for Evaluating the Microstructure of Graphite in Iron Castings" (1998).

[26] Diószegi A, Fourlakidis V and Svensson IL, JTH Research Report, Jönköping University, "Microstructure and Tensile Properties of Grey Cast Iron" (2004).

[27] Ry's J, Stereology of Materials, Fotobit-Design, Cracow (1995).

[28] Fra's E, Górny M and López HF, ISIJ Inter., "Eutectic Cell and Nodule Count in Cast Iron: Part II. Experimental Verification", 47 (2007) 269-276.

[29] Fra's E, Górny M and López HF, Metall. Mater. Trans. A, "Mechanism for the Role of Silicon on the Transition from Graphite to Cementite Eutectic in Cast Iron", 43 (2012) 42044218. 